\title{
The Correlation between Social Support and Work-Family Enrichment with Psychological Well-Being among Married Nurses
}

\author{
Sony Wijaya ${ }^{1}$, Ernawaty ${ }^{2}$ \\ ${ }^{1 *}$ Correspondence Author: swijaya9@gmail.com \\ 1,2 Department of Administration and Health Policy, Airlangga University, Surabaya, Indonesia
}

\section{N D E X I N G \\ Keywords:}

Psychological Well-

Being;

Social Support;

Work-Family

Enrichment.
Kata kunci:

Kesejateraan

Psikologis;

Dukungan Sosial;

Pengayaan Kerja-

Keluarga.

\begin{abstract}
A B S T R AC T
Work and family are two domains where adults spend most of their time, and this can lead to role conflict. This study aimed to examine the correlation between social support and work-family enrichment with psychological well-being among married nurses. This research was quantitative study conducted through cross sectional design. Data collection used questionnaires, including work-family enrichment, social support, and psychological well-being questionnaires. The sampling technique used was purposive sampling, with the inclusion criteria was married nurses who have children. The participants were 100 nurses at Gibran Medika Utama healthcare. Data analysis using regression test was done by SPSS. The results obtained were: (1) there was a significant correlation between social support and work-family enrichment with psychological well-being $(F=26036 ; p<0.05$; $R$ square $=0.214)$, (2) social support had a significant correlation with psychological well-being ( $\mathrm{r}=0.252$, $\mathrm{p}$ $<0.05$ ), and (3) work-family enrichment had a significant correlation with psychological well-being ( $\mathrm{r} 0.219 ; \mathrm{p}<0.05)$. For future organization development it is suggested for the organization to conduct programs that consider work family balance. Further research is also suggested to involve other variables such as personality and life satisfaction.
\end{abstract}

Pekerjaan dan keluarga adalah dua domain tempat orang dewasa menghabiskan sebagian besar waktunya, dan hal ini dapat menyebabkan konflik peran. Penelitian ini bertujuan untuk menguji hubungan antara dukungan sosial dan pengayaan kerjakeluarga dengan kesejahteraan psikologis pada perawat yang menikah. Penelitian ini merupakan penelitian kuantitatif yang dilakukan dengan desain cross sectional. Metode pengumpulan data yang digunakan adalah kuesioner yang meliputi kuesioner pengayaan kerja-keluarga, dukungan sosial, dan kesejahteraan psikologis. Teknik pengambilan sampel yang digunakan adalah purposive sampling, dengan kriteria inklusi perawat menikah yang memiliki anak. Partisipan penelitian ini adalah 100 perawat di fasilitas kesehatan Gibran Medika Utama. Data analisis dengan uji regresi menggunakan SPSS. Hasil yang diperoleh adalah: (1) terdapat hubungan yang signifikan antara dukungan sosial dan pengayaan kerja-keluarga dengan kesejahteraan psikologis ( $F=26.036$; $p<0.05$; $R$ square $=0.214)$, (2) dukungan sosial berkolerasi signifikan dengan kesejahteraan psikologis ( $r=0,252, p<0,05)$, dan (3) pengayaan kerja-keluarga memiliki korelasi yang signifikan dengan kesejahteraan psikologis ( $r$ 0,219; $p<0,05)$. Untuk pengembangan organisasi kedepannya disarankan agar organisasi melakukan program yang mempertimbangkan keseimbangan kerjakerluarga. Penelitian lebih lanjut juga disarankan untuk melibatkan variabel lain seperti kepribadian dan kepuasan hidup.

C) 2021JMMR. All rights reserved

Article history: Received 2020-11-16 Revised 2020-12-22 Accepted 2021-02-25

\section{INTRODUCTION}

Work and family were two domains where adult humans spend most of their time. The changing times and the demands of necessity make traditional structures of family in 
Indonesia shift. The demands of economic needs in the globalization era have made many couples decide to become dual earners. Roles shifting in family has made the women's role increases by taking the role as a careers' woman and as a housewife.

The increase of dual earners couple that has children, causes the changing of family responsibilities for men and women. In the previous, woman as a housewife has full responsibility to manage household and take care of the children. This responsibility has changed for dual earners couple, where a husband also gets a shares of task to manage the household and take care of the children. Balancing roles in work and family is a challenge for dual earner couple. Dual role can lead to interpersonal and intrapersonal conflicts experienced by women and men who simultaneously maintain both professional and personal responsibility. The excessive demand of professional and personal task can lead to dual role conflict.

Work and family are important components in human life that require a lot of time and energy spent to manage multiple responsibilities. In addition, roles in work and family have a meaningful impact on satisfaction and psychological well-being (Kossek \& Ozeki, 1998), (Schwartzberg \& Dytell, 1996). The impact of role conflicts besides appearing in the family domain will also affect the work domain. The role conflict can affect work performance of an employee. Dual role conflict in the work-family domain, does not completely lead to negative interactions between the work-family domain, but also makes the two domains can interact positively (Greenhaus, Singh, \& Romila, 2007). Positive interactions between work-family domains can occur because of the ability of the individual to deal with conflicts occured in these two domains. Work-family enrichment is defined as a form of multiple roles, which means roles in work and in the family will influence each other (Frone, 2003). Work-family enrichment occurs when the roles played in the work and the roles played in the family contribute to each other positively and beneficially (Baral \& Bhargava, 2009).

Social support that comes from both the family domain and the work domain is able to expand the individual resources through acquisition skills and positive influences that facilitate work-family enrichment processes (Greenhaus \& Powell, 2006) (Shein \& Chen, 2011). These conditions allow individuals to experience increased performance in their roles as parents and employees. Individuals can receive social support in different ways and from different sources. The combination of multiple sources of support has different beneficial effects for several roles. Work-family enrichment and social support are expected to be able to increase the psychological well-being of the employees. Psychological Well-Being is a condition when an individual can accept their own strengths and weaknesses, has a purpose in life, develops positive relationships with others, becomes an independent person, able to control the environment, and continues to grow personally (Ryff, 1989).

Nurse is a job with a high level of workload and inflexible working hours. Currently, the majority of nurses at Gibran Medika Utama healthcare were married nurses. Based on the results of field observations, many nurses refuse to work overtime because they had a lot of work at home even though their duties have not been completed. In addition, there were also many cases where nurses arrived late because they had to take care of the child's needs first since no one was helps her at home. This condition makes the researcher wanted to conduct a study that aimed to identify the relationship between social support and work 
family enrichment with psychological well-being among married nurses in Gibran Medika Utama.

\section{Study Design and Setting}

\section{RESEARCH METHOD}

This study was a correlational study with a cross sectional research design. This study was conducted to identify the correlation between independent variables (social support and work family enrichment) and dependent variable (psychological well-being). This study was conducted in Gibran Medika Utama during in January-April 2020.

\section{Study Participants}

The respondents of this study were 100 nurses. The sampling technique used was purposive sampling. The inclusion criteria of the respondents included: 1) the respondents were married, 2) the respondents have at least one child under the age of 18 years old and living together, 3 ) the respondents are in the active period of work.

\section{Operational Definition and Variables Measurement}

Work-family enrichment is the role of a person in the work domain that can improve the quality of family life and the role in the family domain can improve the quality of work. Work-family enrichment is measured using the work-family enrichment questionnaire developed by Carlson, Kacmar, Waybe \& Grzywacz (2006).

Social support is support provided from the family domain and the work environment in the form of emotional support or instrumental support to balance work and family responsibilities. Social support is measured using a social support questionnaire made by Antani and Ayman (2003).

Psychological well-being is an individual psychological health based on the fulfillment of positive psychological functions. PWB is measured by the Ryff Scale of Psychological Well Being (RPWB) made by Ryff (1989).

\section{Data Collection}

The data collection method used in this study was questionnaire. In this study, the instruments used were a self-report scale using Likert scale. The questionnaire method was chosen because the participants know about themselves. The instrument in this study was the Social Support questionnaire adapted from Antani \& Ayman to measure the social support from the work and family domains with a total of 10 items (Antani \& Ayman, 2003). Work family enrichment was measured by the work family enrichment scale (Carlson, Kacmar, Wayne, \& Grzywacz, 2006). This questionnaire consists of 2 dimensions (work to family enrichment and family to work enrichment) with a total of 18 items. This questionnaire used a scale that revealed work to family enrichment, consisting of 3 aspects including work family capital, work family affect, and work family development. Meanwhile, the family to work enrichment consisted of 3 aspects including family work affect, family work development, and family work efficiency.

Another instrument used in this study was psychological well-being scale adapted from Ryff's Scale of psychological well-being (Ryff, 1989). This instrument consisted of 42 items and measured 6 dimensions including: Autonomy, Environmental Mastery, Personal 
Growth, Positive Relations with Others, Purpose in Life, and Self-Acceptance. The questionnaire scoring used a Likert scale with a score range within 1 to 4 with categories ranging from strongly disagree to strongly agree.

\section{Data Analysis}

The analytical method used in this study was multiple linier regression aiming to identify the correlation between social support and work family enrichment with psychological wellbeing. Data processing was carried out using the SPSS program to obtain regression values.

\section{Hypothesis Testing}

The hypothesis proposed by the researcher in this study was that work family enrichment and social support have significant relationship with psychological wellbeing among married nurses at Gibran Medika Utama. Hypothesis testing was done using multiple linier regression tests.

\section{RESULT AND DISCUSSION}

The respondents of this study were 100 married nurses. The demographic characteristics of the respondents consisted of gender, age, length of work period, last education, length of marriage period, number of children, age of spouse, and spouse's occupation which are shown in the following table:

Table.1 Demographic Charateristic

\begin{tabular}{|c|c|c|c|}
\hline Aspects & Category & $\mathrm{N}$ & $\%$ \\
\hline \multirow[t]{2}{*}{ Gender } & Male & 36 & 36.0 \\
\hline & Female & 64 & 64.0 \\
\hline \multirow[t]{4}{*}{ Age } & $>50$ years old & 15 & 15.0 \\
\hline & $41-50$ years old & 35 & 35.0 \\
\hline & $31-40$ years old & 30 & 30.0 \\
\hline & $21-30$ years old & 20 & 20.0 \\
\hline \multirow[t]{2}{*}{ Education } & S1 & 87 & 87.0 \\
\hline & D3 & 13 & 13.0 \\
\hline \multirow[t]{3}{*}{ Length of work period } & $>10$ years & 10 & 10.0 \\
\hline & $5-10$ years & 65 & 65.0 \\
\hline & $1-4$ years & 25 & 25.0 \\
\hline \multirow[t]{4}{*}{ Length of Marriage period } & $>15$ years & 18 & 18.0 \\
\hline & $11-15$ years & 38 & 38.0 \\
\hline & $5-10$ years & 27 & 27.0 \\
\hline & 1.4 years & 17 & 17.0 \\
\hline \multirow[t]{5}{*}{ Number of children } & $>4$ & 5 & 5.0 \\
\hline & 4 & 13 & 13.0 \\
\hline & 3 & 18 & 18.0 \\
\hline & 2 & 42 & 42.0 \\
\hline & 1 & 27 & 27.0 \\
\hline \multirow[t]{4}{*}{ Spouse's Age } & $>50$ years old & 17 & 17.0 \\
\hline & $41-50$ years old & 29 & 29.0 \\
\hline & $31-40$ years old & 32 & 32.0 \\
\hline & $21-30$ years old & 22 & 22.0 \\
\hline Spouse's Occupation & Entrepreneur & 21 & 21.0 \\
\hline
\end{tabular}




\begin{tabular}{ccccc}
\hline Aspects & \multicolumn{1}{c}{ Category } & N & $\%$ \\
\hline & Office worker & 42 & 42.0 \\
\cline { 2 - 4 } & Civil servants & 37 & 37.0 \\
\hline
\end{tabular}

Source: Research's' processed data

Based on Table 1. most of the respondents were married nurses with age distribution 41-50 years. The age distribution of the respondents in each category was not significantly different with the age distribution of the spouse age. Most of the respondents had a length of marriage period of 11-18 years and the majority had 2 children, so it can be assumed that the respondents had experienced maturity and a good adaptation degree in their marriage life.

Table.2 Level of Social Support

\begin{tabular}{lccc}
\multicolumn{1}{c}{ Category } & Interval & Frequency & Percentage \\
\hline Very high & $\geq 45$ & 4 & $4.0 \%$ \\
\hline High & $41-45$ & 31 & $31.0 \%$ \\
\hline Moderate & $36-40$ & 44 & $44.0 \%$ \\
\hline Low & $31-35$ & 19 & $19.0 \%$ \\
\hline Very low & $\leq 30$ & 2 & $2.0 \%$ \\
\hline Total & & 100 & $100.0 \%$ \\
\hline
\end{tabular}

Source: Research's' processed data

Data on the table 2 show that the participants had received social support which tended to be moderate (44\%) and high (31\%). Social support comes from the work domain which includes support from superiors and co-workers, while social support comes from the family domain was from extended families and household helpers. The high level of social support will allow the respondents to manage roles in both work and family domain to improve the quality of life in both domains. On the other hand, poor social support will lead to distress and poor life satisfaction.

Social support includes emotional support and practical assistance which has valuable social commodity (Wallace, 2014). Social support can reduce the negative effects of stressors and improve the psychological well-being (Adam, King, \& King, 1996). Social support for people who have dual roles come from two roles, those are work support and family support (Carlson \& Parrewe, 1999).

Most respondents in this study got moderate and high social support from both work domain and family domain. Most of the respondents have 2 children who live with them, there were even respondents who have more than 3 children. This condition makes the respondents need social support from both of domains in order to achieve a work family balance. The forms of social support received by respondents in this study were emotional support and instrumental support. Emotional support consists of motivation, encouragement and being ready to be friends to share stories if the respondent experiences work stress. Whereas instrumental support in the work domain includes direct assistance of providing information or helping directly on assignments, while instrumental support from the family domain can be direct assistance with children care or household tasks.

Social support in the work domain which came from supervisors and coworkers is a very important factor in helping employees to manage both their work and family roles, with support in the form of direct task, emotional encouragement and information assistance that 
will be able to reduce stress levels at work. Consequently, by receiving superiors support from the work domain, individuals were more likely to experience positive source influence that can be transferred to the family domain. Social support from the family domain refers to support received from family members other than individual spouses or children including mother, parent-in-law, aunt, and household helper (maid) that can provide support by providing childcare assistance while the individual busy at work. The collectivism culture in Indonesia allows individuals to easily get support from the extended families. With the support from the family, especially in household duties and childcare, it will encourage workfamily enrichment. Individuals can work calmly and focus because someone has already taken care of their children at home so that the work performance is also maximized, thus gives a positive effect that was transferred from the family domain to the work domain. Social support is one of the most important aspect which helps individual to gain new resources as well as conserving the resources that have been achieve (Hobfoll, 2001) (Seiger, Christine, Wiese, \& Bettina, 2009).

Table. 3 Level of Work Family Enrichment

\begin{tabular}{lccc}
\multicolumn{1}{c}{ Category } & Interval & Frequency & Percentage \\
\hline Very high & $\geq 83$ & 7 & $7.0 \%$ \\
\hline High & $75-82$ & 35 & $35.0 \%$ \\
\hline Moderate & $67-74$ & 40 & $40.0 \%$ \\
\hline Low & $59-66$ & 14 & $14.0 \%$ \\
\hline Very low & $\leq 58$ & 4 & $4.0 \%$ \\
\hline Total & & 100 & $100.0 \%$ \\
\hline Source Research's' & & &
\end{tabular}

Source: Research's' processed data

Table 3 shows that most of the respondents had moderate (40\%) and high (35\%) level of work-family enrichment. Although there were respondents who had a low and very low level of work-family enrichment existed, most of the respondents indicated that their role in work can improve the quality of family life and vice versa. Work-family enrichment is the extent to which experience in one role in either the work domain or the family domain improves the quality of life, which is performance or influences another role (Greenhaus \& Powell, 2006), (Greenhaus \& Parasuraman, 1999).

Based on table 3, most of the respondents had a moderate (40\%) and high (35\%) level of work-family enrichment. All respondents in this study were dual earner partners so that both husband and wife have multiple roles in the work and family domain. The level of work family enrichment that tends to be high can be caused by the majority of respondents who have a length of marriage age of 5-15 years, with that period of time, it will make the couples has good adaptation in household life. In addition, the majority of respondents also had a length of work period of more than 5 years, which causes the respondents to have work experience and were able to manage conflicts in the work domain. The length of work period and the length of marriage age certainly have an influence on the knowledge and skills of individuals in the domain of work and family. Besides that, the long span of time also allows individuals to experience many successful experiences. With this sufficient age of marriage, there was certainly a lot of experience in managing household tasks so that it is 
possible for the couples to have a division of duties and cooperation in carrying out household tasks.

Work family enrichment measured in this study included 2 dimensions, those are work to family enrichment and family to work enrichment. Work to family enrichment, consisted of work family capital, work family affect, and work family development. Meanwhile, family to work enrichment consisted of family work affect, family work development, and family work efficiency. The multidimensional concept of work-family enrichment, which is how roles in the family benefit from work roles through increased resources, positive influence and psychosocial capital that comes from the involvement in work (Carlson, Kacmar, Wayne, $\&$ Grzywacz, 2006). In the process of work family enrichment, the sources resulting from the work roles of individuals can be transferred to their family roles, thereby increasing the quality of life for family enrichment. For example, a manager gives permission to an employee whose child is sick. Likewise, the resources gained from family roles can be transferred to their job roles, which promote family enrichment, for example, a couple who is able to empathize about their husband's work deadlines.

Table. 4 The Level of Psychological Well-Being

\begin{tabular}{lccc}
\multicolumn{1}{c}{ Category } & Interval & Frequency & Percentage \\
\hline Very high & $\mathrm{x} \geq 163.80$ & 0 & $0.0 \%$ \\
\hline High & $132.60 \leq \mathrm{x}<163.80$ & 32 & $32.0 \%$ \\
\hline Moderate & $101.40 \leq \mathrm{x}<132.60$ & 46 & $46.0 \%$ \\
\hline Low & $70.20 \leq \mathrm{x}<101.40$ & 22 & $22.0 \%$ \\
\hline Very low & $\mathrm{x}<70.20$ & 0 & $0.0 \%$ \\
\hline Total & & 100 & $100.0 \%$ \\
\hline
\end{tabular}

Source: Research's' processed data

Based on table 4, it can be seen that there were no respondents who had very low psychological well-being. The majority of the respondents had moderate psychological wellbeing (46\%). Meanwhile, there were still quite a lot of respondents who had low psychological well-being (22\%), which indicates that there was still a need for efforts from health facilities to increase the psychological well-being of working nurses to lead a good quality of life. This study found that work family enrichment had a significant correlation with psychological well-being. This means that the higher the work family enrichment, the higher level of psychological well-being. A person who has a high work family enrichment indicates that the person is able to overcome work family conflicts and has good stress coping in solving problems in either work or family domains. This can help the emergence of personal growth and environmental mastery in nurses. These aspects were part of psychological well-being.

Psychological well-being shows a positive psychological function of individuals (Ryff, 1995). The function of positive psychology itself is a positive attitude towards oneself and others, including a positive attitude towards the situation at hand. In this study, the results showed that the majority of respondents had a moderate level of psychological well-being, and there were still nurses who had low level of psychological well-being. This result showed that efforts are still needed to improve psychological well-being. Psychologically well-being nurses have a good quality of life because the individuals are able to have a positive view of 
themselves, others and the environment, so that they are able to grow and develop into independent individuals and have a purpose in life.

Table 5 The Correlation of Social Support, Work Family Enrichment and Psychological Well-Being

\begin{tabular}{llcccc}
\hline No. & \multicolumn{1}{c}{ Variable } & R & R & F & square \\
\hline 1 & $\begin{array}{l}\text { Social Support, Work Family Enrichment and Psychological } \\
\text { Well-Being }\end{array}$ & 0.434 & 0.214 & 26.036 & 0.017 \\
\hline
\end{tabular}

Source: Research's' processed data

Linear regression test obtained $\mathrm{F}$ score $=26.036$ and $\mathrm{p}$ value $<0.05$, which means that there was a significant correlation between social support, work family enrichment and psychological well-being. This significant relationship showed that respondents who got support from work and family domain and had good family work enrichment had a good psychological well-being. $\mathrm{R}$ square value $=0.214$ means that social support and work family enrichment had an effective contribution of $21.4 \%$ in explaining the psychological well-being. The existence of high social support and work family enrichment for nurses helps them to be able to respond to situations with positive behavior and makes it an experience for sustainable personal growth and development to achieve a good quality of life. Partial correlation between social support and work family enrichment with psychological well-being among married nurses showed in the following table 6:

Table. 6 The Partial Correlation of Social Support, Work Family Enrichment with Psychological WellBeing

\begin{tabular}{lcc}
\hline \multicolumn{1}{c}{ Variable } & r partial & p \\
\hline Social support with Psychological Well-Being & 0.252 & 0.013 \\
\hline Work family enrichment with Psychological Well-Being & 0.219 & 0.000 \\
\hline
\end{tabular}

Source: Research's' processed data

Partial correlation shows the value of correlation between one independent variable with dependent variable by controlling the other independent variable involved in this study. Value of $\mathrm{r}$ partial between social support and psychological well-being was 0.252 with $\mathrm{p}$ value $<0.05$, which means that there was a significant correlation between social support and psychological well-being by controlling work family enrichment variable. Table.6 also shows the results that work family enrichment has a significant correlation with psychological wellbeing with $\mathrm{p}<0.05$. When it viewed from the magnitude of the partial $\mathrm{r}$ score, it can be concluded that social support has a stronger correlation with psychological well-being than work family enrichment.

Social support enables individuals to manage their roles in multiple domains better and reduces the risk of work-family conflict (Kirrane, Melrona, \& Buckley, 2004), (Siu, et al., 2010). In this study, it was found that social support had a significant correlation with psychological well-being. This result is relevant to several previous research results. Previous studies have found that social support had the most significant effect on individual psychological well-being (Israel, Farquhar, Schulz, \& Parker, 2002), whereas other researchers have suggested that emotional support has the strongest effect on individual well-being and 
enrichment (Rao, Apte, \& Subbakrishna, 2003). Other studies also have found that emotional and instrumental supports offer positive effects on well-being (Lu, 2011).

\section{CONCLUSION}

The conclusions of this study are : (1) the majority of nurse get moderate level of social support, and also have a moderate level of work family enrichment and psychological wellbeing, (2) there is significant correlation between social support and work family enrichment with psychological well-being, (3) social support has a stronger correlation towards psychological well-being than work family enrichment. Suggestion for future research is to conduct research using path analysis to identify the direct and indirect effect of social support and work family enrichment on psychological well-being.

\section{ACKNOWLEDGMENT}

We thank to our colleagues who helped in research process, also we thank to all participants at Gibran Medika Utama Healthcare who have been involved in this study.

\section{REFERENCES}

Adam, G., King, L., \& King, D. (1996). Relationship of job and family involvement, family social support, and work-family conflict with job and life satisfaction. Journal of Applied Psychology, 81(4),411-420. https://doi.org/10.1037/0021-9010.81.4.411

Antani, A., \& Ayman, R. (2003). Gender, Social Support and the Experience of Work-Family Conflict. , Milan, Italy. Paper Presented at Europan Academy of Management. Milan, Italy.

Baral, R., \& Bhargava, S. (2009). Antecedents and consequences of work-family enrichment among Indian managers. Psychological Studies, 54(3),213-225. https://doi.org/10.1007/s12646-009-0028-z

Carlson, D., \& Parrewe, P. (1999). The role of social support in the stressors-strain relationship: An examination of work-family conflict. Journal of Management, 25(4),513-540. https://doi.org/10.1177/014920639902500403

Carlson, D., Kacmar, K., Wayne, J., \& Grzywacz, J. (2006). Measuring the positive side of the work-family interface: Development and validation of a work family enrichment scale. Journal of Vocational Behavior, 68,131-164. https://doi.org/10.1016/j.jvb.2005.02.002

Frone, M. (2003). Handbook of Occupational Health PSychology, Edition: 1st chapter Work Family Balance. New York: American Psychological Association. 
Greenhaus, J., \& Parasuraman, S. (1999). Research on work, family, and gender: Current status and future direction. In G. N. Powel (Ed.), Handbook of gender and work (pp. 391-412). Newbury Park, CA: Sage. https;//doi.org/10.4135/9781452231365.n20.

Greenhaus, J., \& Powell, G. (2006). When work and family are allies: A theory of workfamily enrichment. Academy of Management Review, 31 (1),72-92. https://doi.org/10.5465/AMR.2006.19379625.

Greenhaus, J., Singh, \& Romila. (2007). Mentoring and the Work-Family Interface. Handbook of Mentoring at Work, Ed. Belle Ragins and Kathy Kram. Thousand Oaks, CA: Sage.

Hobfoll, S.E. (2001). The Influence of Culture, Community, and the Nested-Self in the Stress Process: Advancing Conservation of Resources Theory. Jounal of Applied Psychology, 50(3),337-421. https://doi.org/10.1111/1464-0597.00062.

Israel, B., Farquhar, S., Schulz, A., \& Parker, E. (2002). "The relationship between social support, stress, and health among women on Detroit's East Side. Journal of Health education behaviour, 3,342-360 . https://doi.org/10.1177/109019810202900306.

Kirrane, Melrona, \& Buckley, F. (2004). The influence of support relationships on work-family conflict: differentiating emotional from instrumental support. Equal Opportunities International, 23,78-96. https://doi.org/10.1108/02610150410787800.

Kossek, E., \& Ozeki, C. (1998). Work- family conflict, policies, and the job-life satisfaction relationship: a review and directions for organizational behavior/human resources research. Journal of Applied Psychology, 83,139- 149. https://doi.org/10.1037//00219010.83.2.139.

Lu, L. (2011). A Chinese longitudinal study on work/family enrichment. Journal of Career Development International, 16(4),385-400. doi.org/10.1108/13620431111158797

Rao, K., Apte, M., \& Subbakrishna, D. (2003). Coping and Subjective Wellbeing in Women with Multiple Roles. International Journal of Social Psyciatry, 49(3),175-84. https://doi.org/10.1177/00207640030493003.

Ryff, C. (1989). Happines is everything, or is it? Exploration on the meaning of Psychological Well Being. Journal of Personality and Social Psychology, 7,1069-1081. https://doi.org/10.1037/0022-3514.57.6.1069. 
Ryff, C. (1995). Psychological Well Being in Adult Life. Current Direction in Psychological Science, 4(4),99-104. https://doi.org/10.1111/1467-8721.ep10772395.

Schwartzberg, N., \& Dytell, R. (1996). Dual-earner families: The importance of work stress and family stress for psychological well-being. Journal of Occupational Health Psychology, 1(2),211-223. https://doi.org/10.1037//1076-8998.1.2.2.11.

Seiger, Christine, P., Wiese, \& Bettina, S. (2009). Social support from work and family domains as an antecedent or moderator of work-family conflicts? Journal of Vocational Behavior, 75,26-37.

Shein, j., \& Chen, P. (2011). Work Family Enrichment : A Research of Positive Transfer. Canada: Sense of Publisher : University of Toronto.

Siu, O., et. al. (2010). Role resources and work-family enrichment: The role of work engagement. Journal of Vocational Behavior, 77,470-480. https://doi.org/10.1016/j/jvb.2010.06.007.

Wallace, C. (2014). The Support-Based Factors That Facilitate Work-Family Enrichment for Working Fathers in South Africa. A dissertation submitted in partial fulfilment of the requirements for the award of the Degree of Master of Social Science in Organisational Psychology. Cape Town: University of Cape Town. 